\section{ARTHRITIS, FIBROSITIS AND GOUT.}

By C. W. BuckLEY, M.D., F.R.C.P. Pp. 154+viii, 14 plates. H. K. Lewis and Co. Ltd., London, 1938. Price 7/6.

This is a short but fairly complete handbook of certain aspects of the chronic rheumatic diseases. The author has very wisely included a great deal of his own personal experiences and so the textbook is more valuable than many of those which merely give the known facts of these diseases.

About a third of the book is devoted to rheumatoid arthritis and the remaining chapters include osteoarthritis, spondylitis, fibrositis and gout, so that chronic interstitial neuritis is not included. All the more recent forms of treatment are given and their value assessed.

This book both in its contents and in its layout, is definitely superior to the average run of handbooks of this type and can be strongly recommended to practitioners whose knowledge of the subject has fallen out of date.

\section{CHRONIC INTERSTITIAL TOX EMIA AND ITS TREATMENT.}

\author{
By James W. Wiltsie, A.B., M.D. Pp. \\ 270+xii. Baillière, Tindall \& Cox. \\ London. 1938. Price 13/6.
}

In a foreword by Dr. Bastedo, mention is made of the fact that colon irrigation needs not only a knowledge of its therapeutic possibilities but also of its limitations. The author has borne this in mind and has written a book which deals with chronic alimentary toxæmia and its treatment by colon irrigation, with wisdom and restraint.

Although he deals with this aspect of treatment very extensively, he mentions some personal experiences with other forms of treatment and was partly driven to his present beliefs by the failures of these treatments to produce relief. This may be a good or it may be a bad reason, but it shows enterprise and in this case at any rate the enterprise has been controlled by scientific standards.

Some chapters are devoted to considerations of the anatomy and physiology of the colon and to certain considerations of the autonomic nerves system, although the latter sometimes go rather beyond text-book teaching. Focal and systemic infection is considered with citation of cases, and a chapter is devoted to bacterial allergy.

The book should really be read by practitioners, the various techniques bf colon irrigation are considered in detail with the various types of apparatus and fairly sound reasons are given for choosing this or that technique. On the whole this is the best book to be written so far on the subject and perhaps Dr. Wiltsie hits the nail on the head when he says that "This procedure has never enjoyed the whole-hearted endorsement of the medical profession and .... is generally regarded with a feeling of irritation." This feeling-if it exists-will be considerably diminished when this book has been carefully studied.

\section{CLINICAL ROENTGENOLOGY OF THE DIGESTIVE TRACT.}

By Maurice Feldman, M.D. Pp. xvi + 1,014. Figs. 358. Baillière, Tindall \& Cox. London. 1938. Price 45/-.

This book gives a thorough review of diagnostic radiology of the alimentary system, including the cesophagus, stomach and intestines, and also the gall bladder, pancreas, liver and spleen. There is a very satisfactory historical review and a summary of the incidence, etiology, and pathology of each disease. The radiological methods of investigation, and the appearances likely to be found are clearly and fully described. The book is divided up into 220 chapters, some of which are only one paragraph in size, but each is complete with references, drawn mainly from the American and English literature, but not omitting the German and the French.

The frequent use of the split infinitive and the repeated statement that a given disease or condition is revealed by "the X-ray" are irritations which interrupt a text otherwise easy to read.

The author in his preface states that "in collecting the necessary material, an 
enormous amount of literature was perused in order to present the subject from all roentgenologic angles." This is certainly true, for not only are there an enormous number of references, but the text shows that they have been read. The references are also quite up-to-date. The 338 radiographs are helpful in the majority of cases, but it would have been better if they had all been negatives, or all positives, instead of the mixture. The quality of some of the pictures is poor.

As a work of reference, summarising the literature of the subject, and with its description of conditions both common and rare, the book should be available to every radiologist. To clinicians it will show what can be expected of radiology. For students, and even for candidates for radiological diplomas, the $1,000^{\circ}$ pages contain too much food for easy digestion, and a lighter diet is recommended.

\section{GAS AND AIR ANALGESIA.}

By R. J. Minnitt. Baillière, Tindall \& Cox. London. 1938. Price 3/-.

Posterity will indeed be grateful to Dr. Minnitt for writing this handbook on a method of analgesia which is fast changing midwifery practice in this country.

To Dr. Minnitt must be given the credit for designing and popularizing a practical machine, and this book will now make the administration of gas and air a simple and safe procedure in the hands of practitioner and midwife alike. It will also be found invaluable to those anæsthetists who have to give lectures on the subject to midwives, for it includes synopses of four lectures, and suggests suitable questions for an oral examination.

It is to be regretted that in this, which must be the most authoritative work on the method, no mention is made of the father of gas and air analgesia-Guedel-who designed a machine "For the self-administration of gas and air." An illustration is to be found in Gwathmey's " Anæsthesia," published in 1914, with the comment " $\mathrm{He}$ (Guedel), recommends it specially for confinement cases."

Except for this omission, the book gives a complete resumé of the steps that led up to the publication of the regulations issued by the Central Midwives Board. It is well illustrated and should be read by every obstetrician, general practitioner, and midwife.

\section{Forthcoming Medical Books.}

H. K. LEWIS \& CO., LTD.,

136, Gower Street, W.C.1.

"The Infant." A Handbook of Management. By W. J. Pearson, D.M., F.R.C.P., Physician i/c Children's Department, University College Hospital, and A. G. Watkins, M.D., M.R.C.P., Physician in Children's Diseases, Cardiff Royal Infirmary. Second Edition. Crown 8vo. 2s. 6d. net.

"Diet and Ill-health in the Forest Country of the Gold Coast." By F. M. Purcell, M.D., M.R.C.P. With 61 illustrations. Demy 8vo. 7s. 6d. net.

"Cancer: Causation, Prevention and Treatment." By A. E. Blackburn, M.D. With 14 illustrations. Demy 8vo. 6s. net.
"The Streptococcal Tendency." By J. D. Hindley-Smith, M.A.

"Equanimitas" : With other Addresses to Medical Students, Nurses and Practitioners of Medicine. By Sir William Osler, Bt., M.D., F.R.S., late Regius Professor of Medicine, Oxford; Honorary Professor of Medicine, Johns Hopkins University. With a portrait of Sir William Osler, and a Biographical Note by Sir Walter LangdonBrown, M.D. (Cantab.), F.R.C.P. With Three Additional Addresses. Third Edition. Demy 8vo. 7s. 6d. net.

"Harley Street from Early Times to the Present Day." By Percy Flemming, M.D., F.R.C.S., F.S.A. With four illustrations. Demy 8vo. 2s. 6d. net. Paper Boards. 